\title{
MORINGA OLEIFERA - A NEVER DIE TREE: AN OVERVIEW
}

\section{SWATI ${ }^{1}$, AMANPREET KAUR VIRK ${ }^{1}$, CHANDRESH KUMARI ${ }^{1}$, AALIYA ALI ${ }^{1}$, PRAKRATI GARG ${ }^{1}$, PRATIBHA THAKUR ${ }^{1}$, CHANDRIKA ATTRI ${ }^{1,2}$, SAURABH KULSHRESTHA ${ }^{1,2 *}$}

\author{
${ }^{1}$ Department of Applied Sciences and Biotechnology, Shoolini University of Biotechnology and Management Sciences, Bajhol, Solan, \\ Himachal Pradesh, India. ${ }^{2}$ Center for Omics and Biodiversity Research, Shoolini University of Biotechnology and Management Sciences,
} Bajhol, Solan, Himachal Pradesh, India. Email: sourabhkulshreshtha@shooliniuniversity.com

Received: 21 June 2018, Revised and Accepted: 09 August 2018

\begin{abstract}
Moringa oleifera (MO) is mostly inhabiting in the tropical and subtropical regions of the world. It is notable for its therapeutic and nutritious qualities on the grounds that each piece of this plant can be exploited for restorative and sustenance purposes. The restorative and healthful qualities are because of the nearness of certain essential and optional metabolites contained by the plant. The phytochemicals screening uncovered the occurrence of auxiliary metabolites. These bioactive mixes can be utilized as a part of curing numerous ailments. MO is a versatile plant whose seeds comprise an excellent consumable oil (up to $40 \%$ by weight) and water-solvent protein that acts viable coagulants for water and wastewater treatment. The fruitful utilization of shelled MO Lam. seeds as a biosorbent presents a more affordable ecologically inviting technique for the expulsion of different irresistible metals from contaminated watery media. Aside from turbidity expulsion, MO, additionally, has antibacterial properties. The aim of this review is to present a complete analysis of the traditional uses and pharmacological properties of MO. Furthermore, this review is to update wide numbers of phytochemical constituents which have been isolated from the plant, and these constituents possess several medicinal properties.
\end{abstract}

Keywords: Moringa oleifera, Phytochemical, Antibacterial, Biosorbent.

(c) 2018 The Authors. Published by Innovare Academic Sciences Pvt Ltd. This is an open access article under the CC BY license (http://creativecommons. org/licenses/by/4. 0/) DOI: http://dx.doi.org/10.22159/ajpcr.2018.v11i12.28049

\section{INTRODUCTION}

India is a heritable emporium of numerous restorative and fragrant plants. The established literature written in Vedas encodes the hugeness of these therapeutic plants and bushes for different medications. Plants are having different applications else than going about as prescriptions such as sustenance supplements, nutraceuticals, and so on. The helpful properties of plants are known since human progress began. Rigveda demonstrates the therapeutic utilization of plants and recognized to be the most established writing of human information. Likewise, their remedial properties hold an awesome financial incentive over the world.

We are honored with rich herbal assets making a range out of plants crosswise over nation. In Siddha, Ayurveda, and Unani framework, around 1500 plants are used as a fraction of indigenous therapeutic framework. In any case, the discoveries of restorative adequacy of plants have just been attempted by botanists, microbiologists, ethnopharmacologists, and characteristic item scientists. In spite of the fact that there are drugs that are being used for treating irresistible ailments yet there is a noteworthy medication safety concern with respect to them.

It is accounted for that roughly 2.22 million patients with antagonistic medication responses are hospitalized and 1.06 lakh side each year in U.S.A. In the case of natural herbal products, in spite of being utilized over the years, there has been not very many occurrences of such antagonistic responses. Plants are outstanding among other vital asset for drugs, nourishments, supplements, and nutraceuticals [1]. The therapeutic plants create certain synthetic substances which significantly affect the physiology of the human body. Many of the indigenous medicinal plants are used as spices [2].

Moringa oleifera (M0) is a genus of 14 species of flowering plant in the family Moringaceae, which is notable for their therapeutic significance, out of which MO is most contemplated and furthermore known as nebeday or tree that never dies. It is an early developing, dry season tolerant plant that can increase up to 3 meters of tallness inside a limited ability to focus 10 months. It can likewise withstand assortment of soils and precipitation conditions. Moringa is prominent among the most helpful therapeutic plants which can be employed as micronutrient to cure numerous ailments.

\section{TOPOGRAPHICAL SOURCES AND DISTRIBUTION}

MO is a native of Himalayas of North-Western India. This assortment is located in the Sub-Himalayan district from the waterway Chenab toward the Eastwards Sarda and at the zone of Uttar Pradesh in India. Afterward, this species has been developed to diverse parts of the mainland, for example, Malaysia, the Philippines, Singapore, Sri Lanka, Cuba, and Burma. In Africa, the plant has been spread in Nigeria, Egypt, and Sudan; in addition, spread to Central and South America, Peru to Mexico, Paraguay and different urban communities of the world $[3,4]$.

\section{MORPHOLOGY AND PHYSICAL CHARACTERISTICS OF MO}

MO is a quick developing, unending tree which can reach up to 7-12 m of stature and $20-40 \mathrm{~cm}$ distance across. It requires loamy and sandy soil with a marginally acidic to basic $\mathrm{pH}$ and a net precipitation of 250-3000 mm [5].

\section{Stem}

The stem is normally straight yet infrequently being ineffectively framed. The plant develops with a straight, short stem that achieves tallness of 1.5-2 $\mathrm{m}$ and can reach up to $3.0 \mathrm{~m}$ before branching starts.

\section{Branch}

Its shelter is in the state of umbrella, and broadened branches are in a scrambled way.

\section{Leaves}

Pinnate leaves are for the most part developed at the tip of branch and are 20-70 cm long. They are grayish-wool amid an early time of development with long petiole having 8-10 sets of pinnae and 
each combine comprise two opposites, obovate or elliptic match of flyers with one leaf at the zenith having a length of $1-2 \mathrm{~cm}$; petioles and pinnae bear organs at their base [6]. The nourishing contrasts in the leaves collected from two biological areas - semi-deciduous and Savannah locales were contemplated [7]. MO leaves can be fused in the eating regimen of hens and layers consequently giving great protein source, substituting other costly fixings, for example, soybean supper and groundnut cake $[8,9]$

\section{Flowers}

Its flowers have a lovely aroma with a width of $2.5 \mathrm{~cm}$, delivered in axillary, hanging panicles $10-25 \mathrm{~cm}$ long. They are cream or white hued and yellow-spotted at the base. State of reflexed sepals is straight lanceolate with slender-spatulate petals. They encompass the five stamens and five staminodes [6]. Moringa flowers are utilized to make tea with hypocholesterolemic properties. At the point when Moringa flowers are browned, suggest a flavor like mushrooms [10].

\section{Fruits}

The branches are 20-60 cm long and comprise three-lobed podded fruits. After drying, they open into 3 sections containing 12 and 35 seeds each.

\section{Seeds}

Seeds comprise a caramel semi-porous seed body with a round shape. The body comprises 3 white wings at $120^{\circ}$ interims, running top to bottom. Around 15,000 and 25,000 seeds/year can be delivered by each tree. The standard weight of the seed is $0.3 \mathrm{~g}$, and the kernel to hull proportion is 75:25 [11]. In addition to that, every part of the tree is helpful (Table 1), subsequently, create high enthusiasm among analysts. This species has been known and called "miracle tree." The parts of the plant including root, leaves, seeds, and flowers are utilized as medications and are regularly lifesaving $[12,13]$. The shelled and non-shelled MO seeds contain around $37 \%$ and $27 \%$ of protein, respectively [14].

The different capacities and various estimations of MO plant demonstrate its importance for commercial application and income generator to the spots where the species are accessible. Seeds are the most helpful, nutritious herbal item with high financial qualities. It is likewise perceived as restorative and natural cures and have been utilized as a part of the mechanical and farming field in light of the fact that the nearness of a few chemicals it contains as classified in Table 2. Seeds are consumable in fresh, dried form or with the seed cases. The seeds restorative properties are very much recorded and encouraged by the experience of the customary Ayurvedic practitioners [16]. The seed extract is normal coagulant, generally utilized at household for decontamination of water in few towns of Africa, for example, Sudan. This seed extract overcome up to $95 \%$ of water turbidity issue, despite the fact that it regularly relies on the underlying turbidity level [17]. The seeds indicate comparative impact as an alum and less effective in low turbidity water [18]. The seeds contain proteins which are fundamental in water cleansing. It has the capacity to remediate water contamination and several varieties of sicknesses [16]. The National Charity for Organic Growing detailed that MO seeds are used for the treatment of sexually transmitted sicknesses, rheumatism, urinary diseases gout, and epilepsy [19].

\section{DESCRIPTION}

MO is a deciduous tree, long-lasting, short, thin with hanging branches, develops to around 10 meters in stature; stem and branches are fragile; leaves are light green, fluffy with numerous little pamphlets, stamens are yellow; flowers are fragrant, white or velvety white; pods are triangular, brown containing around 20 seeds implanted in the pith. The tallness of Moringa plant can achieve $12 \mathrm{~m}$ with a trunk of $30 \mathrm{~cm}$ wide.

\section{TAXONOMICAL CLASSIFICATION OF MO TREE}

The ordered portrayal for MO was recovered from the Integrated Taxonomic Information System (ITIS, 2018) an online database [21].
Table 1: The functions of $M$. oleifera tree parts $[3,15]$

\begin{tabular}{ll}
\hline Plant part (s) & Function \\
\hline $\begin{array}{l}\text { The leaves protect damping-off } \\
\text { of seedling in the soil }\end{array}$ & Bio-pesticide \\
Flower nectar & \\
Wood and bark & Honey \\
Seed oil & Ornamental, rope and pulp \\
& Raw vegetable mixture for more \\
nutritional value \\
Powdered seed & Flocculate contaminants \\
Seed cake & Honey juice-clarifier \\
Leaves juice expressed & Fertilizer \\
Tree trunks & Foliar nutrient \\
Leaves and fruit cover & Gum \\
Wood & Green manure \\
Living tree & Blue dye \\
Crushed leaves & Covering houses \\
Husk and pod & Cleaning agent for domestic use \\
Leaves and seeds-cake & Biomass production \\
Leaves & Animals food source \\
\hline
\end{tabular}

Table 2: Chemicals found in M. oleifera seeds

\begin{tabular}{ll}
\hline & Chemicals \\
\hline Arachidic-acid & 28-Isoavenasterol \\
Ash & Alpha-tocopherol \\
Brassicasterol & 4-(Alpha-L-rhamnosyloxy)-benzyl \\
& isothiocyanate \\
Beta-Carotene & Behenic-acid \\
Campestanol & Beta-sitosterol \\
Carbohydrates & Fiber \\
Cholesterol & Oleic-acid \\
Fat & Palmitic-acid \\
Glucosinolates & Protein \\
Stearic-acid & Water \\
4-(Alpha-L-rhamnosyloxy) & 2,4-Methylene-cholesterol \\
-benzylglucosinolate & \\
\hline
\end{tabular}

Adapted from [3,20], M. oleifera: Moringa oleifera

The MO otherwise called drumstick tree is one of the 14 varieties having a place in the monogeneric family Moringaceae [22]. The Moringaceae family are identified with Brassicaceae and other 15 families that create mustard oil [23].

- Kingdom - plantae

- Subkingdom - Viridiplantae

- Infrakingdom - Streptophyta - arrive plants

- Superdivision - Embryophyta

- Division - Tracheophyta -vascular plants, tracheophytes

- Subdivision - Spermatophytina - spermatophytes, seed plants

- Class - Magnoliopsida

- Superorder - Rosanae

- Order - Brassicales

- Family - Moringaceae - moringas

- Genus - Moringa

- Species - M. oleifera Lam. - horse radish tree, horseradish tree

\section{VERNACULAR NAMES OF MO}

Due to their wide dissemination, both cultivated and naturally, the tree is outstanding under numerous vernacular names, i.e., ENGLISHDrumstick tree, West Indian ben, Mother's Best Friend, Horseradish tree; FRENCH- Ben Oleifera, Benzolive, Arbreradis du cheval, Bènailé; HINDI-Shajmah, Mungaara, Segra, Shajna; GERMAN-Behenussbaum, Pferderettichbaum, Behenbaum, Flügelsanigerben nussbaum; ITALIANSàndaloceruleo; PORTUGUESE-Muringa, Acáciabranca, Marungo, and Moringuiero; SPANISH-Moringa, Ben, and Morango [4,24]. 


\section{ORIGIN AND HABITAT}

MO is broadly developed type of the Moringaceae family and a standout among the most critical therapeutic plant that is local to the SubHimalayan tracts of India, Afghanistan, Pakistan, and Bangladesh. MO tree was utilized by the Egyptian, Greeks, and old Romans. It is profoundly esteemed from old time as an effect of its enormous therapeutic properties.

\section{PLANT ECOLOGY AND CULTIVATION}

MO is entirely a tropical plant and develops well at lower elevations, both under wet and occasional conditions, however, can be found up to $1300 \mathrm{~m}$ height. It can be developed in different soils, however, flourishes best in prolific and well-drained sandy loams. In India, the tree is proliferated by planting limb cutting $1-2 \mathrm{~m}$ long, from June to August, ideally. The plant begins bearing pods 6-8 months in the wake of planting, however, bearing regular commence after the $2^{\text {nd }}$ year of plantation. The tree bears for several years. The plant flourishes best on forest zone running from subtropical dry to soggy through tropical extremely dry to sodden forest life zones. MO is accounted for to endure yearly temperature of $18.7-28.5^{\circ} \mathrm{C}, \mathrm{pH}$ of $4.5-8$, and yearly precipitation of $4.8-40.3 \mathrm{dm}$. The plant develops best on a dry sandy soil and is drought resistant.

MO is effectively developed by cutting or by seeds. Seeds can be sown either specifically or in holders. No seed pre-treatment is required, and seeds grow promptly in 1-2 weeks. Plants raised from seed create product of irregular quality. Shield maturing is fruitful, and grown trees start to hold up under in a half year and keep on giving a decent harvest for 13 years. As it is basically a vegetative propagative crop, reproducing strategies such as mass choice, exploitation, single-plant determination, and preservation of vigor are transgressive. Stem cuttings are, generally, favored in light of the fact that they root effectively. At the point when developed for its underlying foundations, seeds are now and again planted in rows like vegetable [25].

\section{TRADITIONAL USES}

In general, the flowers, leaves, roots, and bark are utilized as a part of solutions for tumors, stomach distress, conjunctivitis, hypertension, and skin infection, and so forth. Root bark of Moringa yields an alkaloid, moringinine which goes about as cardiovascular stimulant [26], Anticancer [27], hepatoprotective, and anti-inflammatory [28,29] activities in different tissues of Moringa plant has been accounted for. Leaves from Moringa are viable to decrease thyroid hormone [30]. The Philippine ladies expend Moringa leaves blended in shellfish and chicken soup to upgrade breast milk production [31]. Agriculturists add leaves to animal feed to keep up sound domesticated animals [32]. The bark is antifungal, abortifacient, antibacterial, and emmenagogue. Bark can serve for tanning; it likewise yields a coarse fiber [33]. Youthful leaves and branches are savored by domesticated animals. The leaves are crushed and utilized for cleaning dividers and scouring utensils. Its flowers are guaranteed to be cholagogue, stimulant, diuretic, and tonic helpful to expand the stream of bile. The pods are accepted to be anthelmintic, antipyretic and are utilized for the treatment of diabetes. Moringa pods additionally contain amino acids, for example, arginine and histidine. The delicate pods are cooked or pickled and utilized as a part of the culinary arrangement. The new beans after roasting make tasteful dish [34]. Crisp root is bitter and vesicant (has the essence of horse-radish). Internally, it is utilized as antilithic, stimulant, and diuretic. Its gum is adhesive and flat. The root juice is utilized as a heart tonic, antiepileptic, utilized for anxious debility, asthma, expanded liver, and spleen. Relatively all aspects of the plant are of incentive for sustenance (Fig. 1).

Seed is said to be eaten like a peanut in Malaya. The foliage is eaten as green in salads, in vegetable curries, as pickles, and for flavoring. The oil removed from seed is unscented and clear; thus, it is consumable and valuable in the fabricate of scents and hair dressings. MO wood yield blue dye. Researchers outlined Moringa noodles by three strategies of cooking noodles, sautéing, steaming, and boiling [35]. These noodles were tried on rats, and the impacts on mammary organs were contemplated.

\section{PHYTOCHEMISTRY}

"Phyto" is a Greek word which implies that plants and phytochemicals are for the most part identified with plant pigments. The nearness of various kinds of phytochemicals in specific plants can act as a natural defense system giving protection against such things as an assault from creepy crawlies, microorganisms, and brushing creatures. Yet, current research showed that they can likewise shield people from sicknesses [36]. Hence, when consumed in the eating regimen, they may decrease the danger of age-related chronic diseases, for example, hypertension, several kinds of tumor, diabetes, and coronary illness.

MO is enriched with several sugar components, for example, rhamnose and furthermore couple of interesting mixes known as isothiocyanates and glucosinolates $[37,38]$. Moringinine and Moringine are the two detailed alkaloids from its stem [27]. The stem of MO is additionally known to contribute with vanillin, $\beta$-sitostenone, 4-hydroxymellin, $\beta$-sitosterol, and octacosanoic acid [39]. On treating entire gum of MO with gentle hydrolysis and corrosive mixes, some compounds (L-arabinose, L-galactose, L-glucuronic corrosive, and L-rhamnose, L-mannose, and L-xylose) are separated, then again,fromahomogeneous, corrupted gum polysaccharide; L-galactose - glucuronic corrosive and L-mannose are found after same technique [40]. Its flowers contain 9 amino acids; D-glucose, sucrose, wax, couple of alkaloids, kaempferol, and quercetin; moreover, calcium and potassium are found in rich amount as a part of its fiery remains [41]. They are likewise referred to contribute flavonoid pigments, for example, alkaloids, rhamnetin, kaempferol, isoquercitrin, and kaempferitrin [39]. The acetate stage of the ethanol extract gives the antihypertensive mixes thiocarbamate and isothiocyanate glycosides from Moringa pods [42]. Its fruits comprise the cytokinins [43], 0-ethyl-4-( $\alpha$-L-rhamnosyloxy)benzyl carbamate. MO seeds, leaves, and roots were broken down and found to contain the glucosinolates and phenolics, and no anthocyanidins or proanthocyanidins were identified [38]. Once more, this study supports the prior work of Saleem [44]. The phytochemicals have been isolated from MO leaves, seeds, flowers, pods, and stems, majorly the compounds, for example, phenolic acids, glucosinolates, and flavonoids. The flavonol quercetin (principally as the glucoside) present in the leaves has concentrations as high as $100 \mathrm{mg} / 100 \mathrm{~g}$. Other imperative constituents are benzylamine, rutin, myricetin, kaempferol rhamnoglucoside, chlorogenic corrosive, moringinine, and the glycosides niaziminin, and niazinin. Vitamins such as beta-carotene of Vitamin A, Vitamin B, for example, folic corrosive, pyridoxine and nicotinic corrosive, and Vitamin C, D, and E are available [45]. The phytochemicals, for example, sterols, terpenoids, tannins, saponins, anthraquinones, flavonoids, alkaloids, and diminishing sugar are available alongside anticancer agents, for example, glycoside compounds, glucosinolates glycerol1-9-octadecanoate, and isothiocyanates [46]. To get an insight about its antioxidant protection properties, thin-layer chromatography investigation was performed. In addition to these examinations, qualitative investigation of extract revealed the nearness of flavonoids, phenolics, and little measure of alkaloids, in both mature and delicate leaves [47].

\section{ANTIOXIDANT PROPERTIES}

The prefix "anti" implies resistance to or remedial in nature. Oxidants are the substances which oxide alternate substances. "Antioxidant" is a substance that when introduce in low concentration with respect to the oxidizable substances essentially delays or diminishes oxidation of substrate [48]. The strong antioxidant properties of restorative plants may enhance the ability of plants to survive under contaminated conditions. The antioxidant compounds are present in several amounts from various MO tree leaves [31]. Antioxidative properties of phenolic acid in MO seeds emerge from its great reactivity as electron or hydrogen contributors from the capacity to keep up, delocalize the unpaired 


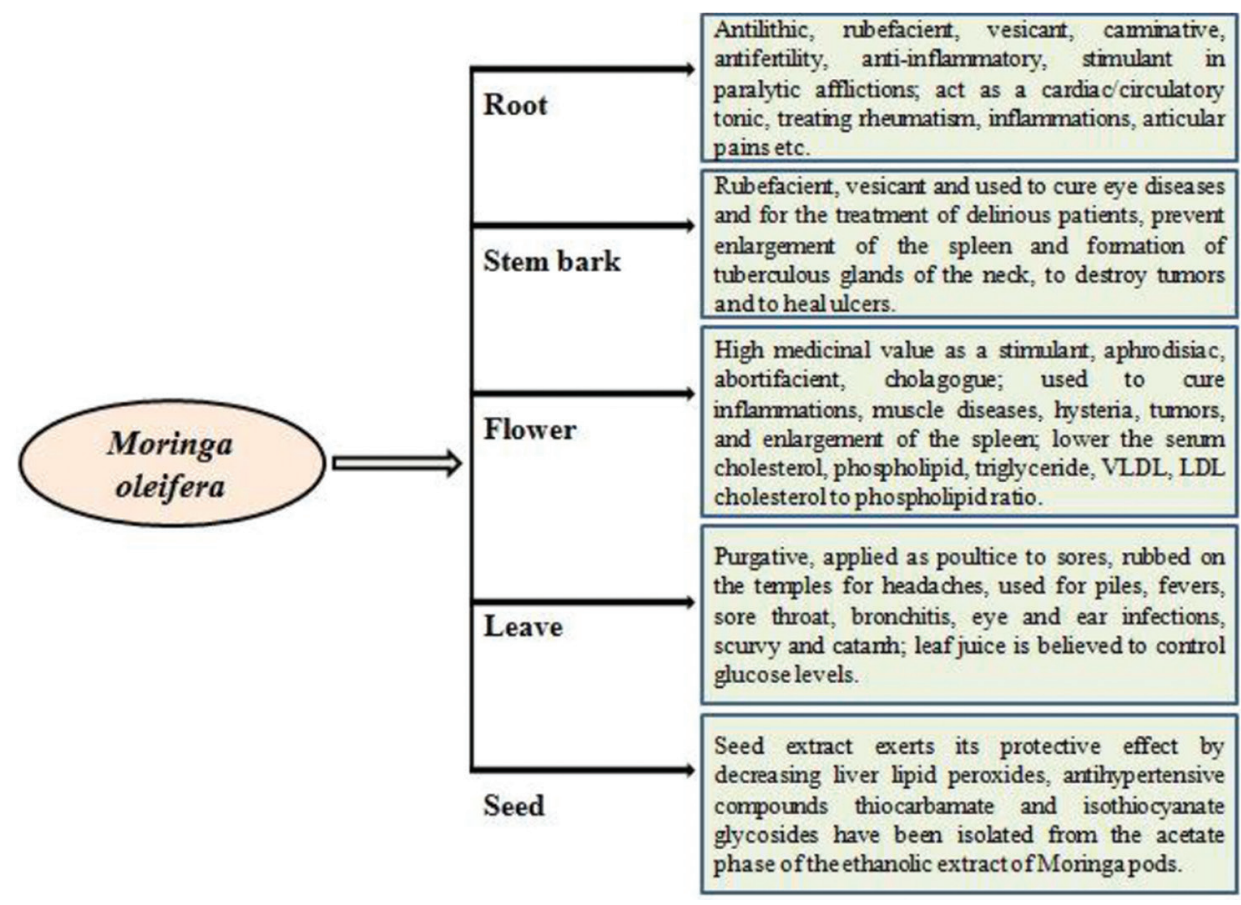

Fig. 1: Common medicinal uses of various parts of Moringa oleifera

electron (chain-breaking capacity), and chelate metal-particles (fenton response eliminator). While, flavonoids antioxidative activities are due to the scavenging of free radicals and chelation of metal-particles [49]. Antioxidants assume a fundamental physiological part in purifying wastewater [50].

MO is a rich mine of antioxidants. The effect of aqueous and ethanolic leaves extracts of MO acquires antiproliferative and antioxidant properties [51]. Moringa with its antioxidant scan diminish the responsive oxygen species (ROS), in this manner protecting the brain [52]. The antioxidant properties in the aqueous extract of seeds, fruit, and leaf of MO were demonstrated [53]. Antioxidant property of freeze-dried MO leaves separated from various strategies, gave a thought that Indian origins ethanol and methanol extracts of MO have the most elevated antioxidant activity of $66.8 \%$ and $65.1 \%$, respectively [31,54]. In addition to this information, [31,55] presumed that the major bioactive compounds of phenolics, as kaempferol and quercetin are traits for antioxidant activity. Kaempferol and quercetin are additionally answered to have great antioxidant activity on hepatocyte development factor-induced Met phosphorylation with IC50 esteem for 12 and $\sim 6 \mu \mathrm{m} / \mathrm{L}$, respectively [56]. A correlation between palm oil with MO seeds against their antioxidant potential reasoned that MO seed can act as chief radical scavengers [57]

\section{PHARMACOLOGICAL ACTIVITY}

MO has a nature of restorative incentive with high sustenance value. This plant is referred to be mineral-rich plant as its few sections encode a scope of vital minerals and are an astounding wellspring of protein, vitamin, $\beta$-carotene, and so on. Likewise, it has convincing water sanitizing forces and high nutritional value.

Moringa's seeds are thought to be acrid, antipyretic, unpleasant [58], and furthermore, the antimicrobial action of this plant is accounted for [59]. The seed additionally fills in as common coagulants for water treatment [60] as it's seed can be dried and pulverized and squeezed into cake, which contain polypeptides. The day by day measurement of $70 \mathrm{~g}$ of Moringa is prescribed to be great and forestalls over a collection of supplements [61]. There was a significant drop recorded in CRP level, paw edema volume, arthritis score, and paw thickness on treatment with diclofenac sodium, aqueous, and ethanolic extracts of Moringa [62].

\section{ANTITUMOR ACTIVITY}

MO comprises numerous bioactive compounds that serve as antitumor agents. These compounds are niazimicin, hinders tumor promoter teleocidin B-4-incited Epstein-Barr Virus actuation, and thiocarbamate announced as a strong anticancer action [26].

\section{ANTIDIABETIC ACTIVITY}

MO has been appeared to cure both Type 1 and Type 2 diabetes. Various examinations have demonstrated that Moringa can act as an antidiabetic agent. The aqueous extract of $\mathrm{MO}$ can cure streptozotocininstigated Type 1 diabetes and furthermore insulin safe Type 2 diabetes in rats [63]. In a further report, the scientists encouraged the STZprompted diabetes rats with Moringa seed powder and saw that the fasting blood glucose dropped [64]

\section{ANTICANCER ACTIVITY}

It has been assessed that approximately 1000 out of 250,000 plants species existing on earth are known to have anticancer activity. Many of species have been selected through various bioassays for the exploration of novel plant-based anticancer drugs [65]. MO has other trademark which creates it a decent compliment to a counteractive action of tumor or treatment design. It can be utilized as an anti-proliferative agent, that restrain the development of growth cells. MO seed extract revealed activity against hepatic carcinogen-metabolizing enzymes and is known to have anticancer. The exploration demonstrates that the ROS incited in the cells, prompts apoptosis. This is additionally demonstrated by the up-regulation of caspase 3 and caspase 9, which are a piece of the apoptotic pathway [66-68].

\section{ANALGESIC ACTIVITY}

MO has been accounted for its analgesic activity. Hotplate and tail immersion strategy [69] conveyed utilizing an alcoholic extract of MO leaves and seeds demonstrated a confirmation about the analgesic action of Moringa. 


\section{ANTI-INFLAMMATORY ACTIVITY}

In most of the cases, inflammation is the body's reaction to another procedure instead of an ailment or infection in its own particular right. Inflammation is a consequence of the body's own particular natural invulnerable reaction and is typically caused by the expanded nearness of plasma white platelets in the influenced territory. This reaction includes the immune system reaction and the vascular frameworks and is an essential piece of the healing procedure yet can cause serious issues when the inflammation becomes chronic or is extreme in its duration or extent. In sub-acute toxicity studies, no mortality was detected when the two doses of 1 or $2 \mathrm{~g} / \mathrm{kg}$ day of $50 \%$ aqueous ethanolic extract in combination were administered for 28 days in mice [70].

\section{ANTIASTHMATIC ACTIVITY}

Alkaloids present in Moringa plant acts like ephedrine and can serve to treat asthma. These alkaloids unwind bronchioles. Bronchial asthma is successfully treated utilizing seed kernels of MO and furthermore enhanced respiratory capacities [71].

\section{HYPOLIPIDEMIC AND ANTIOBESITY ACTIVITY}

MO has been accounted for its hypolipidemic and antiobesity activity too. Methanolic extract of leaves was tested against high-fat dietinduced obesity in rats which indicated positive outcomes affirming that Moringa is useful for weight administration [72]

\section{ANTIHELMINTIC ACTIVITY}

Methanolic concentrates of MO seeds have been assessed against helminths demonstrating this plant is more valuable to humanity [73]

\section{CHOLESTROL LOWERING ACTIVITY}

The presence of bioactive phytoconstituents, outstandingly $\beta$-sitosterol [74] in the crude extract of MO leaves indicated vital cholesterol bringing down activity in the serum of high-fat diet fed rats. Fruit of MO brings down phospholipids, serum cholesterol, triglycerides, and atherogenic index lipid and decreased the lipid profile of liver, heart, and aorta in hypercholesteremic rabbits and aides in expanding fecal cholesterol discharge [75].

\section{BLINDNESS AND EYE INFECTIONS}

Seeds of MO contain the substantial extent of Vitamin A that aides in avoiding eye issues in youngsters and night visual impairment. MO juice is additionally useful in conjunctivitis [76].

\section{ANTIUROLITHIATIC ACTIVITY}

Root-wood of MO was demonstrated to have antiurolithiatic action [77]. Male albino Wistar rats were supplemented with aqueous and alcoholic extract of MO root wood which reduced elevating urinary oxalate consequently demonstrating an administrative activity on endogenous oxalate synthesis.

\section{CARDIAC AND CIRCULATORY STIMULANT}

A few sections of MO go about as the circulatory and cardiovascular stimulant. A cardiovascular stimulant, i.e., Morginine, display in the numerous parts of MO follow-up on the sympathetic nervous system [76].

\section{ANTIHYPERTENSIVE ACTIVITY}

Juice of MO steadily affects blood pressure [34]. MO leaves comprise mustard oil glycosides, thiocarbamate glycosides, and nitriles that help in bringing down blood pressure [78].

\section{ANTISPASMODIC, HEPATOPROTECTIVE AND ANTIULCER ACTIVITIES}

Ethanolic extract of roots of MO has been accounted for to have antispasmodic action, and methanolic extract of leaves has hepatoprotective and antiulcerogenic impacts in rats $[77,79,80]$. Roots of MO indicates hepatoprotective activity [41].

\section{COSMETIC USE}

Ben oil or Behan oil derived from the MO seeds is widely utilized as a bearer oil in cosmetic arrangements [81]. It is utilized as a part of fragrances and furthermore utilized as a watch oil, however, was replaced long back by sperm oil.

\section{LARVICIDAL AND PUPICIDAL ACTIVITY}

Methanolic extract of MO seeds consists of specific phytochemicals that are effective mosquito vector control agents [82].

\section{ANTIFUNGAL AND ANTIBACTERIAL ACTIVITIES}

An antimicrobial is a substance that executes or restrains the development of microorganisms, for example; microscopic organisms, protozoans, and fungi. As indicated by microorganisms, the antimicrobial pharmaceuticals can be gathered, and they act basically against. MO roots are known for their antibacterial action [76] and are considered well-to-do wellspring of antimicrobial agents. Pterygospermin ISIS an effective fungicidal and antibacterial and also reported to be a piece of Moringa's contributions [41]. Flower is additionally found to encode a comparable compound to be in charge of the fungicidal and antibacterial impacts. The fresh leaf juice is useful to repress the development of microorganisms that are pathogenic to man, for example, Staphylococcus aureus and Pseudomonas aeruginosa [81]. The extract of Moringa root bark indicated antifungal action [83], while the juice taken from the stem bark demonstrated to have an antimicrobial impact against $S$. aureus [75]. The ethanol extract of chloroform fraction, brings about the aglycone of deoxy-niazimicine (N-benzyl, S-ethyl thioformate) from the root bark and it is likewise in charge of the antibacterial and antifungal activities [84]. To screen the extract for preparatory additive/disinfecting properties for foods, antimicrobial action of the ethanol and chloroform extract of seeds and leaves of MO were examined. The aqueous extract of MO is accounted for to have restraint potential against numerous pathogenic microscopic organisms, for example, S. aureus, Bacillus subtilis, Escherichia coli, and $P$. aeruginosa in a dose-dependent manner [85] and furthermore known to be exceptionally inhibitory for Mycobacterium phlei and B. subtilis [86]. MO leaf extract is additionally perceived to be utilized in checking development of organisms Basidiobolus haptosporus and Basidiobolus ranarums [87]. The methanolic aqueous extract was taken in another investigation to check its action against Scenedesmus obliquus, E. coli ATCC13706, P. aeruginosa ATCC10145, S. aureus NAMRU 325923, Polio infection compose 1 (sabin antibody), HSV 1 (Herpes Simplex infection write 1), and Bacillus stearothermophilus (bacterial strains); a scope of antimicrobial action was accounted for from delicate for $B$. stearothermophilus to resistant for P. aeruginosa [88]. In addition to antibacterial action of MO oils, it also uncovers antifungal activity [89]. An investigation to look at relative antimicrobial action of seed extract against fungi (Rhizopus solani and Fusarium solani) and microscopic organisms (S. aureus, Pasturella multocida, E. coli, and B. subtilis) concluded $P$. multocida and B. subtilis as the most sensitive strains and sensitivity of these strains are likewise affected by cations $\left(\mathrm{Mg}^{2+} \mathrm{Na}^{+}\right.$, $\mathrm{Ca}^{2+}$, and $\mathrm{K}^{+}$] [90]. MO steam distillate was again prepared into another relative correlation for antibacterial and antifungal capacity and as a result, an inhibition pattern in decreasing order is accounted for as; E. coli took after by P. aeruginosa, B. subtilis, Klebsiella pneumonia, and $S$. aureus while, in the event of fungi, Aspergillus niger is finished up to be repressed much broadly took after by Aspergillus oryzae, Aspergillus terreus, and Aspergillus nidulans [91]. Contrary to resistant against P. aeruginosa and Candida albicans for MO in different investigations, one examination utilizing ethanolic extract of seeds, leaves, and flowers demonstrated the antibacterial action against Enterobacter species, Salmonella typhi, E. coli, Streptococcus, P. aeruginosa, Proteus mirabilis, C. albicans, K. pneumonia, and S. aureus [92]. There are a few segments of Moringa that are accounted for with antibacterial action, for example, 4-(4'- O-acetyl-a-L-rhamnopyranosyloxy) benzyl 
isothiocyanate, 4-(a-L-rhamnopyranosyloxy) benzyl glucosinolate, 4-(a-L-rhamnopyranosyloxy) benzyl isothiocyanate, niazimicin, and benzyl isothiocyanate [32].

\section{PROTEIN PROFILING OF MO}

cMoL, a coagulant Lectin, was segregated from MO seeds [93]. Lectins are carbohydrate recognition proteins. Basic investigations uncovered a pH resistant and heat stable protein with 101 amino acids, 11.67 hypothetical pI and 81\% likeness with a MO flocculant protein. Auxiliary structure content was evaluated as $46 \% \alpha$-helix, $12 \%$ $\beta$-sheets, $17 \% \beta$-turns, and $25 \%$ unordered structures having a place with the $\alpha / \beta$ tertiary structure class. Hemagglutinating action (HA) was researched in particular MO tissue extracts. Hemagglutinating activity was identified in $0.15 \mathrm{M} \mathrm{NaCl}$ extracts from rachis inflorescence and flowers $(5 \%, \mathrm{w} / \mathrm{v})$, leaves, seeds, principal tissue of stem, and stem bark $(10 \% \mathrm{w} / \mathrm{v})$. After saline extraction, segregated $\mathrm{cMoL}$ and guar gel section chromatography were dynamic at $\mathrm{pH}$ range between 4.0 and 9.0 agglutinating erythrocytes from human and rabbit blood classifications. Extracts of tissues and cMoL activities were carbohydrates strained; Asialofetuin and azo-casein abolished cMoL HA. The lectin was thermostable at $100.8^{\circ} \mathrm{C}$ for $7 \mathrm{~h}$. Under diminished conditions, polyacrylamide gel electrophoresis uncovered a primary polypeptide band of $26.5 \mathrm{kDa}$; local fundamental cMoL was identified as an exclusive band. Seed lectin arrangements and cMoL demonstrated coagulant activity like aluminum sulfate. This coagulant is commonly utilized as a part of the treatment of water. Furthermore, this method takes into consideration the collection of an expansive number of primers to distinguish helpful markers which at that point can possibly recognize clones, genome mapping, investigation of sexual separation and microbiological connections among human and nature [94,95].

\section{MO SEEDS ACTING AS NATURAL COAGULANT IN WATER WASTE TREATMENT}

The ability to coagulate the contaminations has made the Moringa seed powder of incredible enthusiasm for the scientific world. MO seeds found to contain a coagulant protein. Are combinant MO protein could flocculate Gram-positive and Gram-negative bacterial cells [96]. For this situation, microorganisms can be evacuated by settling in an indistinguishable way from the expulsion of colloids inappropriately flocculated and coagulated water [97]. The seed extract of MO has a huge potential to be used as a disinfectant [98]. A few investigations have revealed the utilization of crude and purified extracts from the seed for coagulation $[99,100]$ and for hardness expulsion [101]. Waste water treatment arrangement by means of coagulation-flocculation to sedimentation-filtration utilizing MO seeds uncovered most extreme suspended and turbidity materials evacuation. Powdered seeds create lesser measure of sludge volume and advances COD evacuation [102]. The seeds have compelling coagulation properties which have been affirmed in research facility. The seeds are neither harmful to people nor creatures. It is, additionally, very productive in lessening microorganisms presence in raw water. Accordingly, water treated utilizing MO seeds is great contrasted with alum [60]. The physicosynthetic treatment demonstrates empowering aftereffects of toxin diminishment. These might be because of generally dynamic flocs shaped at the nearly most extreme seeds dosage. The $\mathrm{pH}$ estimation of the water did not fundamentally influence by seeds, but rather it likewise goes about as $\mathrm{pH}$ corrector [103]. Conversely, when treated utilizing alum the $\mathrm{pH}$ esteem diminished to 4.2. Other than that, conductivity of the treated water fundamentally changed. COD, turbidity, and suspended solids are exceedingly diminished in waste water treated with MO seeds extract. MO seed extract has the ability to evacuate heavy metals such as copper, arsenic, chromium, lead, and cadmium from water [104]. It has been planned that water treated with seeds of MO plant have numerous advantages when compared with different coagulants such as does not influence the $\mathrm{pH}$ of the water, low cost, produces least sludge as contrast with alum $[101,105,106]$, successful in expelling suspended material $[60,105,107]$, hard water softener [108], and more affordable biosorber of cadmium from aqueous medium [109]. MO functionalized with magnetic nanoparticles, for example, iron oxide was discovered useful in surface water treatment by bringing down settling time [110].

\section{CONCLUSION}

A general review of MO plant and its tremendous uses were explained. This plant has a great therapeutic incentive as it has been accounted for to have versatile phytochemical constituents. Diverse extracts of MO contained different phytochemicals, for example, flavonoids, saponins, tannins, alkaloids, and phenols. Antioxidant activity of MO extracts has been found by methods with the expectation of complimentary free radical scavenging tests. The plants contain flavonoids which demonstrate that the sample has antioxidant effects. The immature pods and flowers of MO demonstrated similar measures of linolenic, palmitic, linoleic, and oleic acids. Soluble and solvent extracts of leaves have been demonstrated as anticancer agents. MO seeds contain an assortment of properties that are useful in restorative field, for instance: Buffering limit and antimicrobial properties. The exploitation of Moringa has an additional preferred standpoint over the compound treatment of water since it is natural and has been accounted for as palatable. The Moringa seed extract, both dry and aqueous, has been effectively used to decontaminate water, as it contains cationic polypeptides going about as a characteristic coagulant. Besides, the polypeptide has been appeared to proficiently execute different pathogenic microscopic organisms. It contains a colossal measure of amino acids, nutrients, vitamins, and minerals which are basic for good well-being. It is stacked with potassium, calcium, iron, Vitamin $\mathrm{C}$ and $\mathrm{A}$, protein, and as various properties which advance a healthy body that has the tools to battle cancer. Different examinations have demonstrated that MO causes ROS in cancer cells that prompts necrosis or apoptosis. Different parts of this plant, for example, the bark, leaves, juvenile pods, fruit, roots, flowers, and seeds serves as circulatory and cardiac stimulants, have antipyretic, antihypertensive, antitumor, anti-inflammatory, antispasmodic, antiulcer, antiepileptic, diuretic, antifungal, antibacterial, hepatoprotective, antioxidant, and antidiabetic activities. In general, they serve for the treatment of various sicknesses in the medicinal framework. MO seeds are relied on to play out their activity straightforwardly on microorganisms and cause development restraint.

\section{ACKNOWLEDGMENTS}

The authors would like to thank Prof.P.K. Khosla, Hon'ble Vice-Chancellor, Shoolini University of Biotechnology and Management Sciences, Solan and Foundation for Life Sciences and Business Management (FLSBM), Solan for providing financial support and necessary facilities. We would also like to thank Himachal Pradesh Council for Science, Technology \& Environment (HIMCOSTE) for providing financial support as research grant [SCSTE/F(8)-1/2016-Vol.-I-3818].

\section{AUTHOR'S CONTRIBUTION}

Swati: Swati is working on the development of magnetic nanoparticles using Moringa, to be used for water purification and compiled the whole review article. Chandresh Kumari: Chandresh is working on accessing the nutritional value of Moringa leaves and is also involved in isolation and characterization of some bioactive compounds from various parts of MO. She has contributed that component for review. Amanpreet Kaur Virk/Pratibha Thakur: Aman is working in the potential of Moringa seeds for purification of potable water. Aman along with Pratibha Thakur is also involved in the development of protocol for industrial waste water treatment using Moringa seeds. She has contributed that component for review. Aaliya Ali, Prakrati Garg: Aalia and Prakrati worked on development of ointment formulation using Moringa seeds for wound healing on mouse model system and has contributed the same for the review. Chandrika Attri: Chandrika supervised some of the experiments. Saurabh Kulshrestha: Saurabh Kushrestha is Mentor and group leader. He is involved in the final editing and compilation of the review article. 


\section{CONFLICTS OF INTEREST}

The authors declare that there are no conflicts of interest regarding the publication of this article.

\section{REFERENCES}

1. Tiwari P, Kumar B, Kaur M, Kaur G, Kaur H. Phytochemical screening and extraction. A review. Int Pharm Sci 2011;1:98-106.

2. Mir MA, Sawhney SS, Jassal MM. Qualitative and quantitative analysis of phytochemicals of Taraxacum officinale. Wudpecker. J Pharm Pharm 2013;2:1-5.

3. Mishra G, Singh P, Verma R, Kumar S, Srivastava S, Jha KK. Traditional uses, phytochemistry and pharmacological properties of Moringa oleifera plant: An overview. Pharm Lett Scholar Res Libr 2011;3:141-64.

4. Ramachandran C, Peter KV, Gopalkrishan PK. (Moringa oleifera): A multipurpose Indian vegetable. Econ Bot 1980;34:276-83.

5. Thurber MD, Fahey JW. Adoption of Moringa oleiferato combat undernutrition viewed through the lens of the "diffusion of innovations" theory. Eco Food Nut 2010;48:1-13.

6. Morton JF. The horseradish tree, Moringa pterygosperma (Moringa ceae)-a boon to arid lands? Econ Bot 1991;45:318-33.

7. Asante WJ, Nasare IL, Ochire-Boadu K, Kentil KB. Nutrient composition of Moringa oleifera leaves from two agroecological zones in Ghana. Afr J Plant Sci 2014;8:65-71.

8. Raphael KJ. Effects of substituting soybean with Moringa oleifera meal in dietson laying and eggs quality characteristics of KABIR chickens. J Anim Physio Anim Nut 2015;1:1-6.

9. Olugbemi TS, Mutayoba SK, Lekule FP. Effect of Moringa (M. oleifera) inclusion in cassava-based diets Fed to broiler chickens. Int J Poultry Sci 2010;9:363-7.

10. Arise AK, Arise RO, Sanusi MO, Esan OT, Oyeyinka SA. Effect of Moringa oleifera flower fortification on the nutritional quality and sensory properties of weaning food. Croatian J Food Sci Tech 2014;6:65-71.

11. Makkar HP, Becker K. Nutrients and antiquity factors in different morphological parts of the Moringa oleifera tree. J Agric Sci 1997;128:311-22.

12. Ghebremichael KA. Moringa seed and Pumice as Alternative Natural Materials for Drinking Water Treatment. PhD Thesis, Royal Institute of Technology Sweden; 2004.

13. Nand P, Drabu S, Gupta RK. In vitro antibacterial and antioxidant potential of medicinal plants used in the treatment of acne. Int J Pharm Pharm Sci 2012;4:185-90.

14. Ndibewu PP, Mnisi RL, Mokgalaka SN, McCrindle RI. Heavy metal removal in aqueous system using Moringa oleifera: A review. J Mat Sci Eng 2011;6B:843-53.

15. Fugile KO, Khatana VS, llangantilike S, Singh SP, Scott G. Economics of potato storage in northern India. Quarterly J Int Agric 2000;39:131-48.

16. Amagloh FK, Benang A. Effectiveness of Moringa oleifera seed as coagulant for water purification. Afr J Agric Res 2009;4:119-23.

17. Katayon S, Magat MJ, Asma M, Ghani LA, Thamer AM, Azni I. Effect of storage conditions of Moringa oleifera seed on its performance in coagulation. Bioresour Technol 2006;97:1455-60.

18. Hegazy YM, Molina-Flores B, Shafik H, Ridler AL, Guitian FJ. Ruminant brucellosis in Upper Egypt (2005-2008). Prev Vet Med 2011;101:173-81.

19. Sengupta S, Bisson WH, Mathew LK, Kolluri SK, Tanguay RL. Alternate glucocorticoid receptor ligand binding structures influence outcomes in an in vivo tissue regeneration model. Comparative biochemistry and physiology. Toxicol Pharmacol 2012;156:121-9.

20. Abdulkarim S, Long K, Lai O, Muhammad S, Ghazali H. Some physiochemical properties of Moringa oleifera seed oil extracted using solvent and aqueous enzymatic methods. Food Chem 2005;93:253-63.

21. Integrated Taxonomic Information System (ITIS). Available from: http://www.itis.gov. [Last retrieved on 2018].

22. Jahn S, Musnad HA, Burgstaller H. Tree that purifies water: Cultivating multipurpose Moringa ceae in the Sudan. Unasylva 1986;38:23-8.

23. Chase M, Kesseli R, Bawa K. Microsatellite markers for population and conservation genetics of tropical trees. Am J Bot 1996;83:51-7.

24. Roloff A, Weisgerber H, Lng U, Stimm B. Moringa oleifera LAM 1785. 2009.

25. James AD. Handbook of Energy Crops. New York: Plenum Press; 1983.

26. Guevara AP, Vargas C, Sakurai H, Fujiwara Y, Hashimoto K, Maoka T, et al. An antitumor promoter from Moringa oleifera lam. Mutat Res 1999;440:181-8.
27. Kerharo PJ. Un remede populaire sengalais: Le 'Nebreday' (Moringa oleifera lann.) employs therapeutique sen milieu Africain chimieet pharmacologie. Plantes Med Phytother 1969;3:14-219.

28. Kurma SR, Mishra SH. Anti-inflammatory and hepato-protective activities of fruits of Moringa pterygosperma Gaertn. Ind J Nat Pro 1998a;14:3-10.

29. Kurma SR, Mishra SH. Hepatoprotective principles from stem bark of Moringa pterygosperma. Pharm Biol 1998b;36:295-300.

30. Tahiliani P, Kar A. Achyranthes aspera elevates thyroid hormone levels and decreases hepatic lipid peroxidation in male rats. J Ethnopharmacol 2000;71:527-32.

31. Siddhuraju P, Becker K. Antioxidant properties of various solvent extracts of total phenolic constituents from three different agroclimatic origins of drumstick tree (Moringa oleifera lam.) leaves. J Agric Food Chem 2003;51:2144-55

32. Fahey JW. Moringa oleifera: A review of the medical evidence for its nutritional, therapeutic, and prophylactic properties. Part 1. Trees Life J 2005;1:5.

33. Hartwell JL. Medicinal Characteristic of Moringa oleifera Leaves and Seeds. Ohio, New York: McGraw Hill Company; 1967.

34. Dahot MU. Vitamin contents of flowers and seeds of Moringa oleifera. Pak J Biochem Mol Biol 1988;21:1-24.

35. Kiranawati TM, Nurjanah N. Improvement of noodles recipe for increasing breastmilk: Design of the Moringa noodles. Am J Food SciTech 2014;2014:88-92

36. Krishnaveni Y, Sathish A. Review on diabetes and its medication. Int J Med Pharm Res 2010;4:120-4.

37. Fahey JW, Zalcmann AT, Talalay P. The chemical diversity and distribution of glucosinolates and isothiocyanates among plants. Phytochemistry 2001;56:5-1.

38. Bennett RN, Mellon FA, Foidl N, Pratt JH, Dupont MS, Perkins L, et al. Profiling glucosinolates and phenolics in vegetative and reproductive tissues of the multi-purpose trees Moringa oleifera L. (horseradish tree) and Moringa stenopetala L. J Agric Food Chem 2003;51:3546-53.

39. Faizi S, Siddiqui B, Saleem R, Saddiqui S, Aftab K. Isolation and structure elucidation of new nitrile and mustard oil glycosides from Moringa oleifera and their effect on blood pressure. J Nat Prod 1994;57:1256-61.

40. Bhattacharya SB, Das AK, Banerii N. Chemical investigations on the gum exudates from Sonja (Moringa oleifera). Carbohydr Res 1982;102:253-62.

41. Ruckmani K, Kavimani S, Anandan R, Jaykar B. Effect of Moringa oleifera Lam on paracetamol- induced hepatotoxicity. Ind J Pharm Sci 1998;60:33-5

42. Faizi S, Siddiqui BS, Saleem R, Aftab K, Shaheen F, Gilani AH, et al. Hypotensive constituents from the pods of Moringa oleifera. Planta Med 1998;64:225-8.

43. Nagar PK, Iyer RI, Sircar PK. Cytokinins in developing fruits of Moringa pterygosperma Gaertn. Physiol Plantarum 1982;55:45-50.

44. Saleem R. Studies in the Chemical Constituents of Moringa oleifera Lam and Preparation of the Potential Biologically Significant Derivatives of 8-Hydroxyquinoline. A Thesis; 1995. p. 357.

45. Mbikay M. Therapeutic potential of Moringa oleifera leaves in chronic hyperglycemia and dyslipidemia: A Review. Front Pharmacol 2012;3:24.

46. Berkovich L, Earon G, Ron I, Rimmon A, Vexler A, Lev-Ari S. Moringa oleiferaa queous leaf extract down-regulates nuclear factorkappa B and increases cytotoxic effect of chemotherapy in pancreatic cancer cells. BMC Complement Alt Med 2013;13:212-9.

47. Sreelatha S, Padma PR. Antioxidant activity and total phenolic content of Moringa oleifera leaves in two stages of maturity. Plant Foods Hum Nutr 2009;64:303-11.

48. Halliwell B, Gutteridge J. Free Radicals in Biology and Medicine. $3^{\text {rd }}$ ed. Oxford, UK: Clarendon Press; 1999.

49. Chanda S, Dave R. In vitro models for antioxidant activity evaluation and some medicinal plants possessing antioxidant properties: An overview. Afr J Micro Res 2009;3:981-96.

50. Ferreira PM, Farias DF, Oliveira JT, Carvalho AD. Moringa oleifera: Bioactive compounds and nutritional potential. Rev Nutr 2008;21:431-7.

51. Sanganna B, Chitme HR, Vrunda K, Jamadar MJ. Antiproliferative and antioxidant activity of leaves extract of Moringa oleifera. Int J Curr Pharm Res 2106;8:54-6.

52. Kirisattayakul W, Wattanathorn J, Tong-Un TT, Muchimapura S, Wannanon P, Jittiwat J. Cerebroprotective effect of Moringa oleifera against focal ischemic stroke induced by middle cerebral artery occlusion. Oxid Med Cell Longev 2013;10:Article ID: 951415, 10 Pages. 
53. Singh BN, Singh BR, Singh RL, Prakash D, Dhakarey R, Upadhyay G, et al. Oxidative DNA damage protective activity, antioxidant and antiquorum sensing potentials of Moringa oleifera. Food Chem Toxicol 2009:47:1109-16.

54. Lalas S, Tsaknis J. Extraction and identification of natural antioxidant from the seeds of the Moringa oleifera treevariety of Malawi. J Am Oil Soc Chem 2002;79:677-83.

55. Bajpai M, Pande A, Tewari SK, Prakash D. Phenolic contents and antioxidant activity of some food and medicinal plants. Int J Food Sci Nutr 2005;56:287-91.

56. Labbé D, Provençal M, Lamy S, Boivin D, Gingras D, Béliveau R, et al. The flavonols quercetin, kaempferol, and myricetin inhibit hepatocyte growth factor-induced medulloblastoma cell migration. J Nutr 2009;139:646-52.

57. Ogbunugafor HA, Eneh FU, Ozumba AN, Igwo-Ezikpe MN, Okpuzor J, Igwilo IO. Physico-chemical and antioxidant properties of Moringa oleifera seedoil. Pak J Nut 2011;10:409-14.

58. Oliveira JT, Silveira SB, Vasconcelos IM, Cavada BS, Moreira RA. Compositional and nutritional attributes of seeds from the multipurpose tree Moringa oleifera Lamarck. J Sci Food Agric 1999;79:815-20.

59. The Wealth of India (A Dictionary of Indian Raw Materials and Industrial Products). Raw Materials. New Delhi: Council of Scientific and Industrial Research; 1962. p. 425-9.

60. Ndabigengesere A, Narasiah KS. Quality of water treated by coagulation using Moringa oleifera seeds. Water Res 1998;32:781-91.

61. Asiedu-Gyekye IJ, Frimpong-Manso S, Awortwe C, Antwi DA, Nyarko AK. Micro-and macroelemental composition and safety evaluation of the nutraceutical Moringa oleifera leaves. J Toxicol 2014;2014:1-13.

62. Fatima N, Fatima JS. Pharmacological screening for anti-arthritic activity of Moringa oleifera. Asian J Pharm Clin Res 2016;9:106-11.

63. Divi SM, Bellamkonda R, Dasireddy SK. Evaluation of antidiabetic and anti-hyperlipedemic potential of aqueous extract of Moringa oleifera in fructose fed insulin resistant and STZ induced diabetic wistar rats: A comparative study. Asian J Pharm Clin Res 2012;5:67-72.

64. Al-Malki AL, El Rabey HA. The antidiabetic effect of low doses of Moringa oleifera lam. Seeds on streptozotocin induced diabetes and diabetic nephropathy in male rats. Biomed Res Int 2015;2015:381040.

65. Rajendran S, Saravanan R, Ramalingam S, Hameed SA. Antiproliferative and antioxidant activity of Gynandropsis pentaphylla Linn on MCF-7 cell line. Int J Pharm PharmSci 2014;6:561-5.

66. Tiloke C, Phulukdaree A, Chuturgoon AA. The antiproliferative effect of Moringa oleifera crude aqueous leaf extract on cancerous human alveolar epithelial cells. BMC Complement Altern Med 2013;13:226.

67. Jung IL. Soluble extract from Moringa oleifera leaves with a new anticancer activity. PLoS One 2014;9:e95492.

68. Leelawat S, Leelawat K. Moringa oleifera extracts induce cholangio carcinoma cell apoptosis by induction of reactive oxygen species production. Int J Pharm Phytochem Res 2014;6:183-9.

69. Sutar NG, Bonde CG, Patil VV, Narkhede SB, Patil AP, Kakade RT. Analgesic activity of seeds of Moringa oleifera Lam. Int J Green Pharm 2008;2:108-10.

70. Srivastava R, Srivastava S, Singh SP. Toxicological screening for polyherbal combinations of Moringa oleifera and Embelia ribes in experimental animals. Asian J Pharm Clin Res 2018;11:476-80.

71. Agrawal B, Mehta A. Anti-asthmatic activity of Moringa oleifera Lam: A clinical study. Ind J Pharm 2008;40:28-31.

72. Bais S, Singh GS, Sharma R. Anti-obesity and hypolipidemic activity of Moringa oleifera Leaves against high fat diet-induced obesity in rats. Adv Biol 2014;2014:9.

73. Giri IC, Shamim QM, Khan S, Patel J, Choudhary R, Singh A. Evaluation of the anthelmintic activity of Moringa oleifera seeds. Int $\mathrm{J}$ Pharm Prof Res 2010;1:1.

74. Ghasi S, Nwobodo E, Ofili JO. Hypo-cholesterolemic effects of crude extract of leaf of Moringa oleifera Lam in high-fat diet fed wistar rats. J Ethnopharm 2000;69:21-5.

75. Mehta K, Balaraman R, Amin AH, Bafna PA, Gulati OD. Effect of fruits of Moringa oleifera on the lipid profile of normal and hypercholesterolaemic rabbits. J Ethnopharmacol 2003;86:191-5.

76. Rao MV, Paliyath G, Ormrod DP. Ultraviolet-B- and ozone-induced biochemical changes in antioxidant enzymes of Arabidopsis thaliana. Plant Physiol 1996;110:125-36.

77. Gilani AH, Aftab K, Suria A, Siddiqui A, Salem R, Siddiqui BS, et al. A pharmacological study on hypotensive and spasmodic activities of pure compounds from Moringa oleifera. Phyto Res 1994;8:87-91.

78. Faizi S, Siddiqui BS, Saleem R, Siddiqui S, Aftab K, Gilani AH, et al. Fully acetylated carbamate and hypotensive thiocarbamate glycosides from Moringa oleifera. Phytochemistry 1995;38:957-63.
79. Dangi SY, Jolly CI, Narayana S. Antihypertensive activity of the total alkaloids from the leaves of Moringa oleifera. Pharm Biol 2002;40:144-8.

80. Caceres A, Saravia A, Rizzo S, Zabala L, DeLeon E, Nave F. Pharmacologic properties of Moringa oleifera. 2: Screening for antispasmodic, anti-inflammatory and diuretic activity. J Ethnopharm 1992;36:233-7.

81. Caceres A, Lopez S. Pharmacologic properties of Moringa oleifera: 3: Effect of seed extracts in the treatment of experimental pyodermia. Fitoterapia 1991;62:449-50.

82. Prabhu K, Murugan K, Nareshkumar A, Ramasubramanian N, Bragadeeswaran S. Larvicidal and repellent potential of Moringa oleifera against malarial vector, Anopheles stephensi liston (Insecta: Diptera: Culicidae). Asian Pac J Trop Biomed 2011;1:124-9.

83. Bhatnagar SS, Santapau H, Desai JD, Yellore S, Rao TN. Biological activity of Indian medicinal plants. Part 1. Antibacterial, antitubercular and antifungal action. Ind J Med Res 1961;49:799-805.

84. Nikkon F, Saud ZA, Rehman MH, Haque ME. In vitro antimicrobial activity of the compound isolated from chloroform extract of Moringa oleifera Lam. Pak J Biol Sci 2003;22:1888-90.

85. Saadabi AM, Abu ZA. An in vitro antimicrobial activity of Moringa oleifera L. seed extracts against different groups of microorganisms. Asian J Basic App Sci 2011;5:129-34.

86. Eilert U, Wolters B, Nahrstedt A. The antibiotic principle of seeds of Moringa oleifera and Moringa stenopetala. Planta Med 1981;42:55-61.

87. Nwosu MO, Okafor JI. Preliminary studies of the antifungal activities of some medicinal plants against basidiobolus and some other pathogenic fungi. Mycoses 1995;38:191-5.

88. Ali GH, El-Taweel GE, Ali MA. The cytotoxicity and antimicrobial efficiency of Moringa oleifera seeds extracts. Int J Env Stud 2004;61:699-708

89. Chuang P, Lee C, Chou J, Murugan M, Shieh B, Chen H. Antifungal activity of crude extracts and essential oil of Moringa oleifera Lam. Bioresour Tech 2007;98:232-6.

90. Jabeen R, Shahid M, Jamil A, Ashraf M. Microscopic evaluation of the antimicrobial activity of seed extracts of Moringa oleifera. Pak J Bot 2008;40:1349.

91. Prashith KT, Mallikarjun N, Swathi D, Nayana KV, Aiyar MB, Rohini TR. Antibacterial and antifungal efficacy of steam distillate of Moringa oleifera Lam. J Pharm Sci Res 2010;2:34-7.

92. Nepolean P, Anitha J, Emilin RR. Isolation, analysis and identification of phytochemicals of antimicrobial activity of Moringa oleifera Lam. Curr Biot 2009;3:33-9.

93. Luciana AL, Silva MC, Ferreira R, Santana LA, Silva-Lucca RA, Mentele R, et al. Structural characterization of coagulant Moringa oleifera Lectin and its effect on hemostatic parameters. Int J Bio Macromol 2013;58:31-6.

94. Beyene D. Genetic Variation in Moringa stenopetala germplasm of Ethiopia by using RAPD as Genetic Marker. Ethiopia: Addis Ababa University; 2005.

95. Liu P, Yang YS, Hao CY, Guo WD. Ecological risk assessment using RAPD and distribution pattern of a rare and endangered species. Chemosphere 2007;68:1497-505

96. Broin M, Santaella C, Cuine S, Kokou K, Peltier G, Joët T, et al. Flocculent activity of a recombinant protein from Moringa oleifera lam. Seeds. Appl Microbiol Biotechnol 2002;60:114-9.

97. Casey TJ. Unit Treatment Processes in Water and Wastewater Engineering. London: John Wiley \& Sons; 1997.

98. Bichi MH, Agunwamba JC, Muyibi SA, Abdulkarim MI. Effect of extraction method on the antimicrobial activity of Moringa oleifera seeds extract. J Am Sci 2012;8:450-8.

99. Olsen A. Low technology water purification by bentonite clay and Moringa oleifera seeds flocculation as performed in Sudanese villages: Effects on Schistosoma mansoni cercariae. Water Res 1987;21:81-92.

100. Sutherland JP, Folkard G, Grant WD. Natural coagulants for appropriate water treatment: A novel approach. Waterlines 1990;8:30-2

101. Muyibi SA, Evison LM. Optimizing physical parameters affecting coagulation of turbid water with Moringa oleifera seeds. Water Res 1995;29:2689-95.

102. Bhuptawat H, Folkard GK, Chaudhari S. Innovativephysicochemical treatment of wastewater incorporating Moringa oleifera seed coagulant. J Haz Mater 2007;142:477-82.

103. Anwar F, Latif S, Ashraf M, Gilani AH. Moringa oleifera: A food plant with multiple medicinal uses. Phytother Res 2007;21:17-25. 
104. Ravikumar K, Sheeja AK. Heavy metal removal from water using Moringa oleifera seed coagulant and double filtration. Int J Sci Eng Res 2013;4:5.

105. Jahn SA. Using Moringa oleifera seeds as coagulant in developing countries. J Am Water Works Assoc 1998;6:43-50.

106. Ndabigengesere A, Narasiah KS, Talbot BG. Active agents and mechanism of coagulant of turbid waters using Moringa oleifera. Water Res 1995;29:703-10.

107. Okuda T, Baes AU, Nishijima W, Okada M. Isolation and characterization of coagulant extracted from Moringa oleifera seed by salt solution. Water Res 2001;35:405-10.

108. Muyibi SA, Evison LM. Moringa oleifera seeds for softening hard water. Water Res 1995;29:1099-104.

109. Sharma V, Purohit GR, Arya RS, Harsh M. Evaluation of some complete rations in sheep incorporating unconventional feed resources of arid zone in India. Anim Nut Feed Tech 2006;6:135-41.

110. Santos TR, Silva MF, Nishi L, Vieira AM, Klein MR, Andrade MB, et al. Development of a magnetic coagulant based on Moringa oleifera seed extract for water treatment. Env Sci Pollution Res 2016;14:1-9. 